\title{
Development of coffee seedlings with biostimulants
}

\author{
Wanderson Lopes Moreira $^{1}$ (D), Risely Ferraz-Almeida ${ }^{1}$
}

${ }^{1}$ Universidade de São Paulo/USP, Escola Superior de Agricultura "Luiz de Queiroz"/ ESALQ, Piracicaba, SP, Brasil

Contact authors: wanderson.agro@hotmail.com, rizely@gmail.com

Received in February 25, 2021 and approved in July 28, 2021

\begin{abstract}
Sustainable coffee production has become an alternative to aggregate value to coffee. Biostimulants are presented to increasing coffee quality and production. This study aims to compare and evaluate the application of biostimulants in the initial development of coffee seedlings. An experiment was carried out with applications of biostimulants: (i) 4-indole-3-ylbutyric acid + gibberellic acid + cinetina, AIA+AG+C; (ii) foliar fertilizer + algae, F+A; (iii) vegetal extracts + gibberellic acid, EV+AA. After 94 days of applying the biostimulants, monitored the length of the aerial part (LAP), the number of leaves $(N L)$, stem diameter, root biomass (pivoting, auxiliary and total). Results showed that the $F+A$ promoted the greatest $L A P, N L$, and root biomass. $A I A+A G+C$ showed similar performance as F+A in NL. There was a higher production of auxiliary roots with biostimulants impacting positively on plant paraments. Given the results, we concluded that biostimulants based on mixed foliar fertilizer + algae demonstrated to be a better alternative to increasing the development of the aerial and root part of coffee seedlings.
\end{abstract}

Key words: Coffea sp.; Organomineral; Root system; Phytohormones.

\section{INTRODUCTION}

With the growth of the population and the demand for a better quality of living, there is a challenge of sustainable use of natural resources, minimizing waste production and environmental impacts (Goedert; Oliveira, 2007). Agriculture is one of the most relevant sectors for human and economic development, directly impacting the production of goods and services. Several factors influence agriculture production, among them, the main ones are the conditions of the climate, soil, water availability, and technologies associated with social and economic factors (Paterniani, 2001).

Brazil is the largest producer and exporter of coffee (Coffea sp.), responsible for 35\% of the world's production destined for human consumption in the international market (Empresa Brasileira de Pesquisa Agropecuária Ministério da Agricultura - EMBRAPA Café 2019). According to (Conselho dos Exportadores de Café do Brasil - CECAFE, 2019), in 2019 , Brazilian coffee production was exported mainly to the United States of America (18.7\%: 3.2 million bags of coffee) and Germany (16.7\%; 2.8 million bags of coffee). In that same year, Brazil produced 50.92 million bags, with a reduction in production (down 17\%) compared to 2018; and an increase in production (up to 13\%) when compared to 2017 (Companhia Nacional de Abastecimento - CONAB, 2019)

Sustainable coffee production has become an alternative to aggregate value to coffee, reaching new world markets. Coffee of high quality can be an alternative to increasing profitability mainly to farmers who are experiencing economic difficulties due to the high costs of operations and agricultural inputs. Biostimulants have been presented as an alternative to increasing coffee production acting on the plant's natural self-defense mechanism and insect and disease resistance. Biostimulants are characterized by a combination of growth regulators, amino acids, nutrients (macro and micronutrients), and vitamins (Silva et al., 2012). Oliveira et al. (2019) showed that the application of biostimulants, with plant hormones in their composition, stimulated cell division and elongation in apexes developing leaves and roots. Severino et al. (2003) showed that the application of biostimulants can be an alternative to increase plant growth in germination conditions, especially when applied in the initial phase of the crop.

Based on studies that demonstrated that biostimulants promote the germination rate, emergence, and the initial development of the plants (Oliveira et al., 2019; Severino et al., 2003), studies that demonstrate the effect of biostimulants in coffee seedling are requested, and, therefore, justifying this study. The hypothesis raised was that the biostimulants improve the development of coffee seedlings due to the increases in the root system. This study aims to compare the application of biostimulants in the initial development of coffee seedlings.

\section{MATERIAL AND METHODS}

\subsection{Study Characterization}

The experiment was carried out on a farm located in Monte Carmelo, Minas Gerais, Brazil. The coffee production in the Monte Carmelo region is characterized by high-quality coffee and productivity with a climate classified as Aw, according to Köppen and Geiger, and an average temperature of $21.2^{\circ} \mathrm{C}$ and an annual rainfall of $1444 \mathrm{~mm}$. 
The study was developed in a randomized block design with the applications of biostimulants: (i) 4-indole-3ylbutyric acid + gibberellic acid + Cinetina, AIA + AG+C; (ii) foliar fertilizer + algae, $\mathrm{F}+\mathrm{A}$; (iii) vegetal extracts + gibberellic acid, EV+AA; (iv) control. The 4-indole-3-ylbutyric acid + gibberellic acid + cinetina presents a respective rate of 0.00005 ; 0.00005 ; and $0.00009 \mathrm{~kg} \mathrm{~L}^{-1}$, commercially known by the name Stimulate ${ }^{\circledR}$. The foliar fertilizer + algae is formed on an algae base (Ascophyllum nodosum), known as SeaCrop ${ }^{\circledR}$, with carbohydrates readily assimilated by the plant (i.e., alginic acid, Mannitol, Laminarin, Fucoidan, among others) and nutrients (potassium, $\mathrm{K}_{2} \mathrm{O}, 0.0744 \mathrm{~kg} \mathrm{~L}^{-1}$; and zinc, $0.0124 \mathrm{~kg} \mathrm{~L}^{-1}$ ). Vegetal extracts + gibberellic acid is enriched with minerals complexed by amino acids, commercially known as Crop ${ }^{\circledR}$, contenting $6.0 ; 1.0 ; 3.1 ; 0.09 ; 0.06 ; 1.3 ; 1.0 ; 1.1 ; 0.04 ;$ and 2.3 $\mathrm{pp}^{-1}(\%)$ of carbon, nitrogen, sulphur, boron, cobalt, iron, copper, manganese, molybdenum, and zinc, respectively. A control treatment also was monitored without biostimulant application. Each experimental unit was considered with a seedling, 10 plants per treatment, totaling 40 experimental units.

For the sowing of coffee seeds (variety: Mundo Novo), the soil was collected in the region of Monte Carmelo, presenting a $\mathrm{pH}$ and content of phosphorus, magnesium, calcium, potassium, aluminum, and hydrogen plus aluminum of $5.1 ; 1.5 \mathrm{mg} \mathrm{dm}^{-3} ; 0.1 \mathrm{cmol}_{\mathrm{c}} \mathrm{dm}^{-3} ; 0.1 \mathrm{cmol}_{\mathrm{c}} \mathrm{dm}^{-3} ; 0.06 \mathrm{cmol}_{\mathrm{c}}$ $\mathrm{dm}^{-3} ; 0.40 \mathrm{cmol}_{\mathrm{c}} \mathrm{dm}^{-3}$ and $2.7 \mathrm{cmol}_{\mathrm{c}} \mathrm{dm}^{-3}$, respectively. The substrate was prepared with a mixture of organic fertilizer (bovine manure, composted and sieved: $300 \mathrm{~L}$ ), soil (700 L), and mineral fertilizer applications (5 $\mathrm{kg}$ of simple superphosphate and $0.5 \mathrm{~kg}$ of chloride potassium).

After stabilization and homogenization of the substrate, bags ( $0.18 \mathrm{~m}$ high; $0.04 \mathrm{~m}$ wide) were filled with the substrate. The bags were lined up on the beds, and the selected seeds were planted at an average depth of $0.015 \mathrm{~m}$ deep, directly. Seeds were covered with the substrate and received irrigation to maintain sufficient moisture for germination. With a still damp substrate, the set was covered with a layer to maintain the ideal temperatures for seed development.

Irrigation was carried out periodically to maintain adequate water availability for germination and seedling development. The foliar application of the biostimulants was carried out in the first pair of leaves using the dose of $0.001 \mathrm{~L} \mathrm{~L}^{-1}$ of each commercial product. The application of biostimulants was carried out with a frequency of 20 days between applications, totaling four applications. The frequency of application was based on studies of Silva et al. (2012) and Friedrich et al. (2020), which recommended a frequency between one and three weeks.

\subsection{Measurements}

After 94 days of the biostimulant application, we monitored the aerial part length, the number of leaves, stem diameter, and dry root biomass (pivoting and auxiliary roots). The aerial part length of the plants was evaluated by measuring from the plant neck to the last leaf. To assess the number of true leaves, the leaves that form the embryo (cotyledons) were disregarded, with the count of the total number of leaves. The root dry biomass was determined after the cleaning process in running water to remove all soil and impurities. Parts of plants were dried in the SL-102 Circulating and Renewing Greenhouse to obtain dehydrated root biomass, dry weight of pivoting, and auxiliary roots.

The assumptions of normality and homogeneity of variance were evaluated by the Shapiro-Wilk test and the oneillmathews test $(p \leq 0.05)$, respectively. Data were submitted to ANOVA, based on the F-test. When the F-test was significant $(p \leq 0.05)$, the biostimulants and control were tested by the LSD-test $(p \leq 0.05)$. The variables, aerial part length, stem diameter, and leaf number, dry matter of auxiliary, pivoting, and total roots of coffee seedlings were correlated by the correlation test (Pearson; $\mathrm{p} \leq 0.05)$.

\section{RESULTS}

\subsection{Shoot Growth}

$\mathrm{F}+\mathrm{A}$ promoted the largest length of the aerial part, stem diameter, and the number of leaves in the coffee seedlings with an average, respectively, of $0.32 \mathrm{~m} ; 0.004 \mathrm{~m}$; and 14 leaves. While, $\mathrm{EV}+\mathrm{AA}$ presented a performance similar to the control, and $\mathrm{AIA}+\mathrm{AG}+\mathrm{C}$ showed the second better performance in higher growth of the aerial part, stem diameter, and number of leaves (Figure 1).

\subsection{Root System}

$\mathrm{F}+$ A promoted a greater development of the auxiliary and pivoting roots, and total root system, respectively, with biomass of $0.0029 ; 0.0025 ; 0.0054 \mathrm{~kg}$ (Figure 2). The auxiliary root mass was more sensitive to biostimulants with an increase of 18 and $47 \%$ with applications of $\mathrm{AIA}+\mathrm{AG}+\mathrm{C}$ and $\mathrm{F}+\mathrm{A}$ compared to the control (Figure 2A). Interestingly, $\mathrm{EV}+\mathrm{AA}$ did not significantly increase the pivoting roots with performance similar to control (Figure 2).

As expected, the development of the aerial part was correlated with root growth with an $\mathrm{r}$ between 0.55 and 0.70 $(\mathrm{p} \leq 0.05)$, indicating that the increase in the root system influenced the aerial development. Interestingly, the pivoting roots did not affect the number of leaves with an $\mathrm{r}$ of 0.27 ( $\mathrm{p} \leq$ 0.05 ). In contrast, there was a positive effect of auxiliary root in all plant's paraments. This result was probably due to the low variation and effect of biostimulants on the pivoting root mass (Table 1). 



Figure 1: Aerial part length $(\mathrm{m})$, stem diameter $(\mathrm{m})$, and leaf number of coffee seedlings with biostimulants (i) 4-indole-3-ylbutyric acid + gibberellic acid + Cinetina, AIA+AG+C; (ii) foliar fertilizer + algae, $F+A$; (iii) vegetal extracts + gibberellic acid, EV+AA). C: control. Means were compared by the LSD test $(p \leq 0.05)$.

\section{DISCUSSION}

The performance of $\mathrm{F}+\mathrm{A}$ was significantly superior to other biostimulants with a better growth of aero and root parts of the coffee seedling. The $\mathrm{F}+\mathrm{A}$ was characterized as a foliar fertilizer formed on an algae base (Ascophyllum nodosum), with carbohydrates readily assimilated by the plant (i.e., alginic acid, Mannitol, Laminarin, Fucoidan, among others) and potassium $\left(\mathrm{K}_{2} \mathrm{O}, 0.0744 \mathrm{~kg} \mathrm{~L}^{-1}\right)$ and zinc $\left(0.0124 \mathrm{~kg} \mathrm{~L}^{-1}\right)$. In the initial development, coffee seedling requests higher inputs of macro (nitrogen, potassium, calcium, magnesium, phosphorus, and sulfur) and micronutrients (iron, boron, manganese, zinc, and copper) to the development of aero and roots (Covre et al., 2013). The superior performance of $\mathrm{F}+\mathrm{A}$ is explained by the inputs of nutrients in the substrate by fertilizers and carbohydrates. Castro, Pacheco and Medina (1998), testing the application of $\mathrm{F}+\mathrm{A}$ (rate: $1 \mathrm{~L} \mathrm{ha}^{-1}$ ) also found a positive effect on the number of branches and weight of fruits in the tree of 'pera' sweet orange (Citrus sinensis L. Osbeck).
The AIA $+\mathrm{AG}+\mathrm{C}$ also promoted the number of leaves that presented a result similar to $\mathrm{F}+\mathrm{A}$, probably due to contents of 4-indole-3-ylbutyric acid + gibberellic acid + cinetina with a respective rate of $0.00005 ; 0.00005$; and $0.00009 \mathrm{~kg}$ $\mathrm{L}^{-1}$. Dantas et al. (2012) also demonstrated the positive effect of $\mathrm{AIA}+\mathrm{AG}+\mathrm{C}$ on plant height growth but no significant effect on stem diameter in tamarind trees. Echer et al. (2006) showed an increase in the development of yellow passion fruit seedlings with AIA $+A G+C$. While Ferreira et al. (2007) also did not verify the effect of $\mathrm{AIA}+\mathrm{AG}+\mathrm{C}$ on the productivity of corn grains when applied in seed treatment. The $\mathrm{F}+\mathrm{A}$ also promoted root development, described in this study as the auxiliary and pivoting roots. Interest, the auxiliary root mass was more sensitive to the application of biostimulants with an increase of 18 and $47 \%$ with applications of AIA $+A G+C$ and $\mathrm{F}+\mathrm{A}$ compared to the control. The biostimulants have been recommended as an alternative to promote the root development of plants (Oliveira et al., 2017), confirming with our results the positive effect on the auxiliary root mass. The 
presence of phytohormones (auxin, cytokinin, and gibberellin) in biostimulants promotes the development of the root that acts as mediators of the physiological process, increasing plant growth and development and stimulating cell division with direct effect in the absorption of water and nutrients for plants (Vieira; Castro, 2004). Hartmann et al. (2002) described that there is a balance in the levels of auxins and cytokinins in plants, where high levels of auxins and low cytokinins may favor the formation of adventitious roots, and low levels of auxins and high cytokinins may favor the formation of adventitious shoots. Dias et al. (2012) did not show a significant effect of biostimulant (Promalin ${ }^{\circledR}$ ) in root cuttings of blackberry.
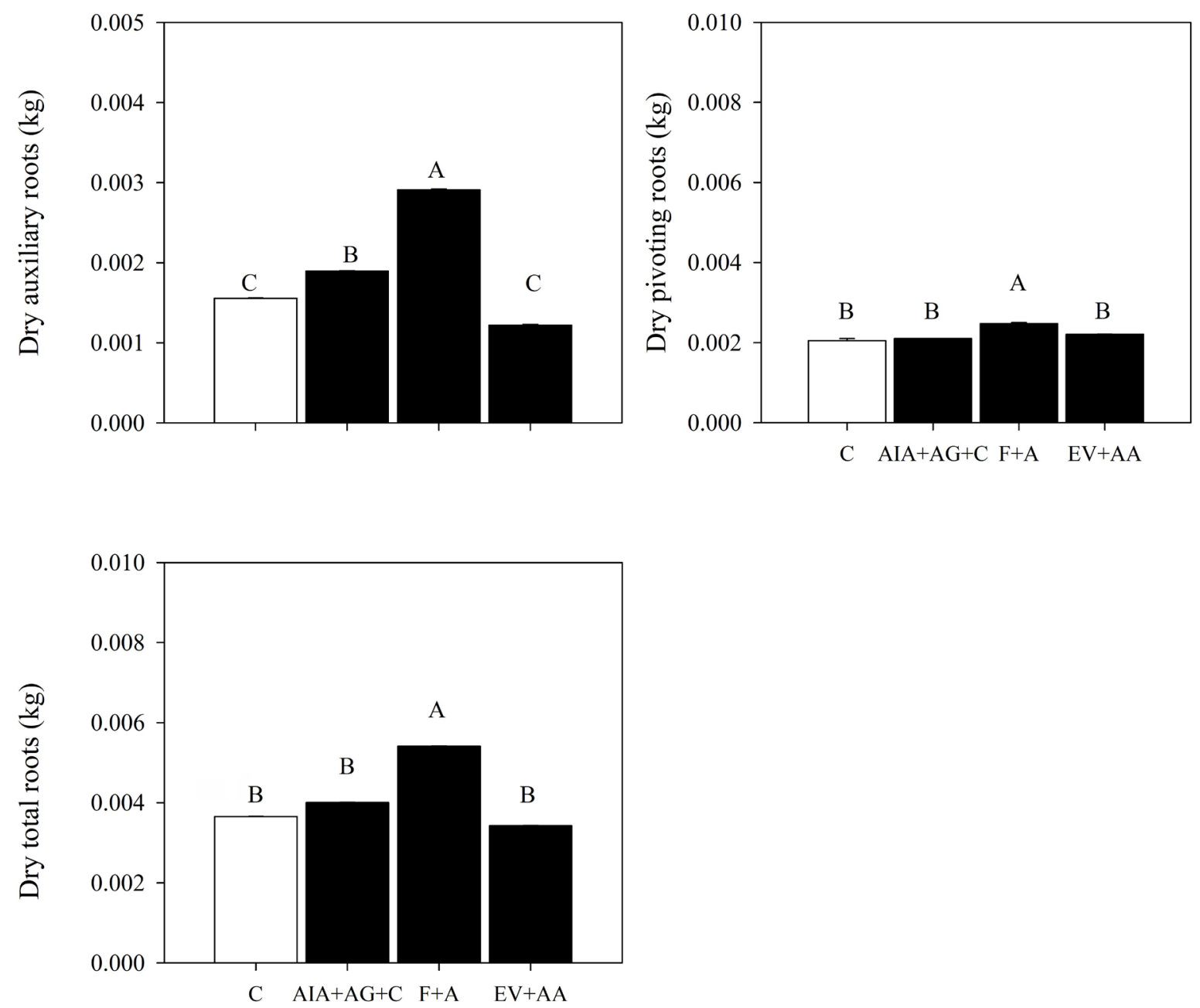

Figure 2: Dry matter of auxiliary, pivoting, and total roots $(\mathrm{kg})$ of coffee seedlings with biostimulants (i) 4-indole-3-ylbutyric acid + gibberellic acid + Cinetina, $A I A+A G+C$; (ii) foliar fertilizer + algae, $F+A$; (iii) vegetal extracts + gibberellic acid, EV+AA. Means were compared by the LSD test $(p \leq 0.05)$.

Table 1: Aerial part length, stem diameter, leaf number, dry matter of auxiliary, pivoting, and total roots of coffee seedlings with the application of stimulants.

\begin{tabular}{cccccc}
\hline & \multicolumn{2}{c}{ Aerial part } & \multicolumn{2}{c}{ Roots } \\
\hline & leaf number & stem diameter & Auxiliary & Pivoting & Total \\
\hline Aerial part & $0.67^{*}$ & $0.58^{*}$ & $0.69^{*}$ & $0.55^{*}$ & $0.70^{*}$ \\
Leaf number & - & $0.60^{*}$ & $0.43^{*}$ & 0.27 & $0.46^{*}$ \\
Stem diameter & - & - & $0.51^{*}$ & $0.39^{*}$ & $0.52^{*}$ \\
Auxiliary roots & - & - & - & $0.88^{*}$ & $0.99^{*}$ \\
Pivoting roots & - & - & - & - & $0.81^{*}$ \\
\hline
\end{tabular}

Variables were compared by the Pearson correlation test $(p \leq 0.05)$. Correlation values with * represent a significant correlation. 
The EV+AA that presents vegetal extracts + gibberellic acid did not present a great performance in plant development which explains that probably there is a dependence on the balance of phytohormones in biostimulants. The influence of biostimulants in root development is important due to their positive impacts on the development of the aerial part.

\section{CONCLUSIONS}

Biostimulants based on mixed leaf fertilizer + algae promote greater length of the aerial part, the number of leaves, and biomass of the pivoting and auxiliary roots. The application of biostimulants based on 4-indole-3-ylbutyric acid + gibberellic acid + kinetin has the same performance as mixed leaf fertilizer + algae in the number of leaves of coffee seedlings. There is a higher production of auxiliary roots with the applications of biostimulants and a positive impact in plant paraments explained by the higher soil volume explored by the roots. Given the results, we concluded that the application of biostimulants based on mixed foliar fertilizer + algae is a better alternative to increase the development of the aerial and root parts of coffee seedlings.

\section{CONFLICT OF INTEREST}

There is no conflict of interest

\section{REFERENCES}

CASTRO, P. R. C.; PACHECO, A. C.; MEDINA, C. L. Efeitos de stimulate e de micro-citros no desenvolvimento vegetativo e na produtividade da laranjeira 'pêra' (Citrus sinensis L. Osbeck). ScientiaAgricola, 55(2):338-341, 1998.

\section{COMPANHIA NACIONAL DE ABASTECIMENTO -} CONAB. Acompanhamento da safra brasileira. Café: Safra 2019. 2019. Segundo levantamento Maio/2019. Avaliable in: $<$ https://www.conab.gov.br/info-agro/safras/ cafe $>$. Access in: January, 22, 2021.

CONSELHO DOS EXPORTADORES DE CAFÉ DO BRASIL - CECAFE. Relatório mensal de exportações 2019. 2019. Avaliable in: < https://www.cecafe.com.br/publicacoes/ relatorio-de-exportacoes $>$. Access in: January, 22, 2021.

COVRE, A. M. et al. Crescimento e desenvolvimento inicial de genótipos de café Conilon. RevistaAgro@mbiente, 7(2):193-202, 2013.

DANTAS, A. C. V. L. eta 1. Effect of gibberellic acid and the biostimulant stimulate ${ }^{\circledR}$ on the initial growth of tamarind. Revista Brasileira Fruticultura, 34(1):8-14, 2012.

DIAS, J. P. T. et al. Bioestimulante na promoção da brotação em estacas de raiz de amoreira-preta. Revista Brasileira de Fruticultura, 34(1):1-7, 2012.
ECHER, M. M. et al. Uso de bioestimulante na formação de mudas de maracujazeiro amarelo. Semina: Ciências Agrárias, 27(3):351-360, 2006.

EMPRESA BRASILEIRA DE PESQUISA AGROPECUÁRIA MINISTÉRIO DA AGRICULTURA

- EMBRAPA. ASSOCIAÇÃO BRASILEIRA DA INDÚSTRIA DE CAFÉ (ABIC). Consumo mundial de café atinge 165 milhões de sacas no ano cafeeiro 20182019.2019. Avialable in: $<$ https://www.embrapa.br/en/ busca-de-noticias/-/noticia/45871233/consumo-mundialde-cafe-atinge-165-milhoes-de-sacas-de-60kg/>. Access in: January, 22, 2021.

FERREIRA, L. A. et al. Bioestimulante e fertilizante associados ao tratamento de sementes de milho. Revista Brasileira de Sementes, 29(2):80-89, 2007.

FRIEDRICH, J. C. C. et al. Bioestimulante: Uso em produção de mudas e resultados na produção comercial. Brazilian Journal of Development, 6(5):27392-27409, 2020.

GOEDERT, W. J.; OLIVEIRA, S. A. Fertilidade do Solo e Sustentabilidade da Atividade Agrícola. In: Novaes, R. F. et al. Fertilidade do Solo. Viçosa, MG, Sociedade Brasileira de ciência do Solo, p. 991-1017, 2007.

HARTMANN, H. T. et al. Plant propagation: Principles and pratices. 7th ed. New Jersey: Prentice-Hall, 2002. 880p.

PATERNIANI, E. Agricultura sustentável nos trópicos. Estudos Avançados, 15(43):303-326, 2001.

OLIVEIRA, W. F. et al. Desempenho agronômico do capimmarando tratado com bioestimulantes de crescimento vegetal no bioma Amazônia. Arquivo Brasileiro de Medicina Veterinária e Zootecnia, 71(2):603-612, 2019.

OLIVEIRA, F. A. et al. Substrato e bioestimulante na produção de mudas de maxixeiro. Horticultura Brasileira, 35(1):141-146, 2017.

SEVERINO, L. S. et al. Aplicação de regulador de crescimento em sementes de algodão, amendoim, gergelim e mamona. Campina Grande: Embrapa Algodão, 2003. 17p. (Embrapa Algodão. Boletim de Pesquisa, 53).

SILVA, D. J. et al. Efeito de bioestimulantes no desenvolvimento de mudas de videira. 2012. Available in: <https://ainfo.cnptia.embrapa.br/digital/bitstream/ item/69673/1/Patricia1.pdf $>$. Accessed on: January, 22, 2021.

VIEIRA, E. L.; CASTRO, P. R. C. Ação de bioestimulante na cultura da soja (Glycine max L. Merrill). Cosmópolis: Stoller do Brasil. 2004. 47p. 